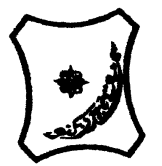

Bayero Journal of Pure and Applied Sciences, 9(1): 150 - 159

Received: December, 2015

Accepted: April, 2016

ISSN $2006-6996$

\title{
ANALYSIS OF THE DISTRIBUTION OF HEAVY METALS IN THE SOILS OF BAGEGA MINING AREA ZAMFARA STATE, NIGERIA
}

\author{
${ }^{1}$ Salisu, K., ${ }^{1}$ Yusuf, M.A., ${ }^{1 *}$ Ahmed, M. ${ }^{1}$ Mohammed, M. U. and ${ }^{2}$ Umar, I. A. \\ ${ }^{1}$ Department of Geography, Bayero University ,Kano State, Nigeria \\ ${ }^{2}$ Kano University Science and Technology, Wudil, Kano State, Nigeria \\ Correspondents author:'ma7766554@gmail.com +2348039661458
}

\begin{abstract}
Uncontrolled exploitation and degradation in the environment over the past few decades as the result of urbanization and poverty has caused a serious damage to lives and properties. The study analysed the spatial distribution of heavy metal (Fe, $\mathrm{Cu}$ and $\mathrm{Zn}$ ) in Bagega, Zamfara state. Three mapping units were identified and samples were collected from the top soil $(0-15 \mathrm{~cm})$ horizon using stratified random sampling techniques. These include the Mining Processing Environment (MPE), Residential exterior (RE) and Surrounding Farmlands (SF). In each mapping units, twelve (12) samples were collected random/y. Coordinates of all samples points were recorded using GPS. The soil sample were analyse for heavy metals using Atomic Absorption Spectrophotometer (AAS) and the result were recorded in Microsoft excel and later transformed into GIS environment in the Arc GIS 10.1 version. Krigging model was used for mapping the spatial distribution of the heavy metals in the study area. The result shows that there are more concentrations of heavy metals (Fe and $\mathrm{Cu}$ ) in the Residential exterior (RE) and streams sites. The level of heavy metal in the soils of the area were below the acceptable toxic level of and this can be attributed to the number of years quarry activities in the study area have been in operation. The study concluded that Fe and Zn are more concentrated to the mining and river sites areas, while $\mathrm{Cu}$ is highly concentrated at the farmlands areas. The study recommends for continuous monitoring and mining should be avoided especially closer to the residential areas.
\end{abstract}

Keywords: Spatial distribution, Mapping, Heavy metals, Bagega

\section{INTRODUCTION}

Soil is the major reservoir for contaminants and has an ability to bind various chemicals. These chemicals can exist in various forms in the soil and different forces keep them bound to soil particles. Diverse amounts of heavy metals may be found everywhere in the soils. Chemicals or heavy metals once introduced to the soils by mining activity may spread to various soil components, which may be caused by the nature of interaction occurring in this natural system (Dube et al.,2000). Many soils contain a wide range of heavy metals with varying concentration ranges depending on the surrounding geological environment and anthropogenic and natural activities occurring (Dube et al., 2000).

There has been an uncontrollable exploitation and degradation of the environment over the past few decades as a result of great technological advancement, rapid industrialization and urbanization. Many urban and rural areas of industrialized world are continually threatened with the uncontrollable wastes from industries as they upset their ecological balance (Okonkwo, 1999). These activities generate high concentration of heavy metals and other elements in the soil which can pose serious effects on the affected communities.

Mining as one of the oldest industries in Zamfara state which started since 1945 by the German. Mining is one of the leading industry in the state has contributed a lot in the socio-economic development of the state. The state has high reserves of solid minerals including gold, copper, zinc etc. The Zamfara solid minerals deposits occur in alluvial and eluvia places and primary vein from several parts of the schist belt in the state. The most important occurrences are found in Maru and Anka areas. After the discovery of solids mineral deposits, many methods have been used to extract them. At the beginning open cast method was normally used. This method was the most destructive form of mining. In areas where it was extensively practiced, it left a present legacy of disturbed land. Since the inception of mining in Zamfara state, illegal mining has continued to dominate mining in the state as it accounts for $90 \%$ of solid minerals mining in the state. Minerals commonly mined include gold, limestone and gypsum. Many illegal mine sites have been identified in the state with several thousands of people directly involved. Since 2009, the price of gold has appreciated substantially, from around US $\$ 800$ per ounce, to US $\$ 1653$ (May 2012). This has resulted in a renewed interest in mining in Zamfara state. An increasingly active gold mining industry digs up rock by hand, breaks them into pebbles with hammers, grinds the pebbles to sand with flour mills, and extracts gold from the sand using sluicing, panning and mercury amalgamation (and in some cases cyanidation). 
Usually the health problems associated with gold mining are related to the mercury and or cyanide used. In Zamfara where the gold bearing deposits contain unusually problematic concentration of lead and other heavy metals, the crushing of pebbles into sand in dry running flour mills produces enormous amounts of dust which in some places is highly contaminated with lead and possibly some other heavy metals (Nigeria Ministry of Mines and Steel Development, 2010) .

Many researchershave shown the adverse impacts resulting from mining activities, like studies of Dubeet al.,(2000), Ezigbo(2011) and Lar (2013) to mention few. For example,pollution of mining industries in Brazil comes from gold mining activities. The mercury used to concentrate gold became extremely high in the tropical ecosystem (Salomom, 1995). Another mining problem was found at the Sam Quintin mine area in Spain, whereRodriquizet al., (2009) said that $\mathrm{Pb}, \mathrm{Zn}$, and $\mathrm{Ag}$ were in high concentrations as a result of mine wastes generated during mining activities.

Thus, series of studies has been conducted in the study area (Bagega) which is a rural area in Anka local government of Zamfara State (Nigeria). Most of these studies targeted the concentration and distribution pattern of heavy metals in soils (Adamuet al., 2011; Tsuwang et al., 2014; Yusuf et al., 2007), on water contaminations (Lar, 2013; Mark et al 2014; Majiyaet al 2015;), effect on health (Yi-Chun et al 2012; Dooyemaet al. 2012; CDCP, 2012; Galadima,
2012), to mention few. But attempt has not been made in mapping out the spatial distribution of these elements in the study area (Bagega). Analyzing the spatial distribution of a phenomenon will allow to clearly viewing the spread and variation which will help in the interpretation of the analysis. Thus, helps in identifying the concentration ofthe parameters (Ahmed et a/ 2015).

\section{STUDY AREA}

Bagega mining environment is located in Anka Local Government Area, which lies between latitude $11^{0} 32^{\prime}$ and $12^{\circ} 29^{\prime}$ North of the equator and longitude $5^{\circ} 40^{\prime}$ and $6^{0} 18^{\prime}$ East of the Prime Meridian. It is bordered in the North East by TalatanMafara, South and South East by Maru, West by Bukkuyyum, North by Bakura (Figure.1). It has a total land area of 3,265 square kilometers out of which the agricultural land took the highest percent.

According to the 2006 census data, Anka Local Government Area had a total population of 87,340 . The study area (Bagega) has a population of 7,323 (NPC, 2006). The climate has been largely controlled by two air masses namely, the tropical maritime air masses from the Atlantic Ocean and the tropical continental air masses from the Sahara and the Middle East. The climate of Zamfara is therefore dry and wet type classified as (Aw) by Koppen (1918). Throughout the year average maximum temperature is $36^{\circ} \mathrm{C}$ and average daily minimum is $21^{\circ} \mathrm{C}$.

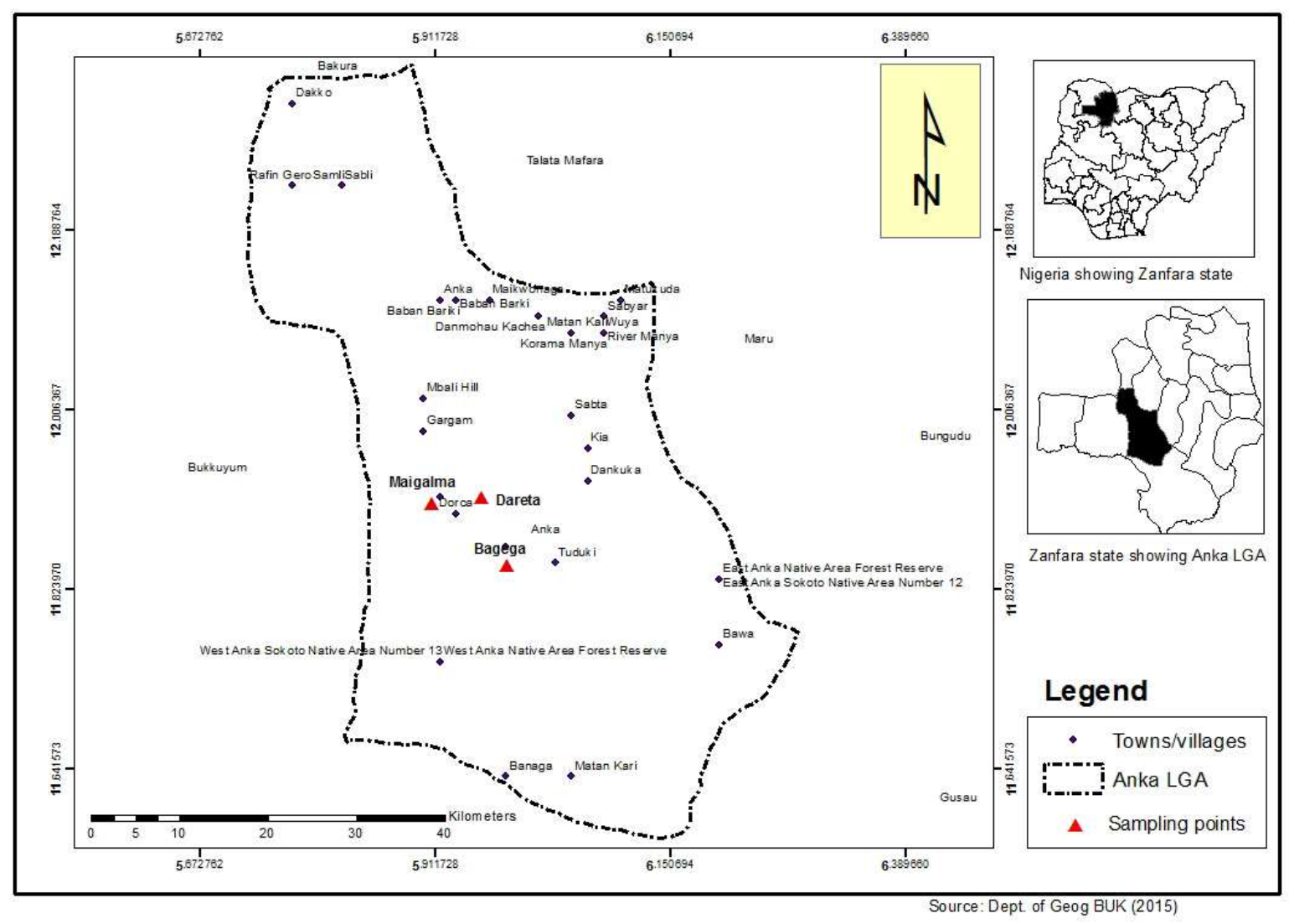

Figure 1: Bagega showing sampling points 
Two major soils types, ferruginous tropical soils and lithosols dominate Zamfara state. The ferruginous tropical soil can be found in the northern and central parts of the state, particularly around Gumi, Bukuyyum, Anka(which include Bagega) and Bakura. Other areas in which such soil occur include TalatanMafara, Zurmi, BirninMagaji, Shinkafi and KauranNamoda. The soils are characterized by a sandy surface horizon, with clayey subsoil, both of which are fertile for agricultural production. They are susceptible to erosion, since the top soil is easily washed off by rain water, especially if the vegetation cover is removed (Physical Setting of Zamfara, 2003). The vegetation of Bagegaarea is falling within Sudan and northern Guinea Savannah. Agriculture is the mainstay of the economy of the State (Zamfara) and engages about 90 percent of the people. Indeed, agriculture provides foodstuff, industrial raw materials and employment opportunities to the people. Geologically, the state is characterized by very old igneous rocks and metamorphic rocks, during the preCambrian era. The two rocks types found are granites and Meta-sediments. The granites (including undifferentiated granites), Gneiss and Migmatites are largely resistant to erosion but when weathered they result into poor soils. The Meta-sediments on the other hand consist of pyrites, quartzite and Metaconglomerates (Physical Setting of Zamfara, 2003).

\section{MATERIALS AND METHODS}

The materials used in the research include sample kits, Base maps, polythene bags, stainless steel shovel, Global Positioning System (GPSGarming 76 cSX model) and measuring Tape.A reconnaissance survey was conducted around the mining processing environment, farm plots surrounding the current mining processing environment and Bagega village. This was to identify the nature of the mine wastes and how they were discharged. The surveyed covered the crushing, grinding, washing and dumped sites of the mining processing area. The five villages selected include Tungardadi, Abare, Duza, Sunke and TungarMalam. Some mining industries were also visited in order to identify their functions. This helps in strategizing the sampling frame. After an initial survey (as reconnaissance), three sampling areas (the study sites) were identified: Some land marks features in the base map were used to identify individual sampling frame. The three areas are Mining Processing Environment (A), Surrounding environment (farmlands) (B) and Residential Exterior (C) (Fig 2). And these are described below:

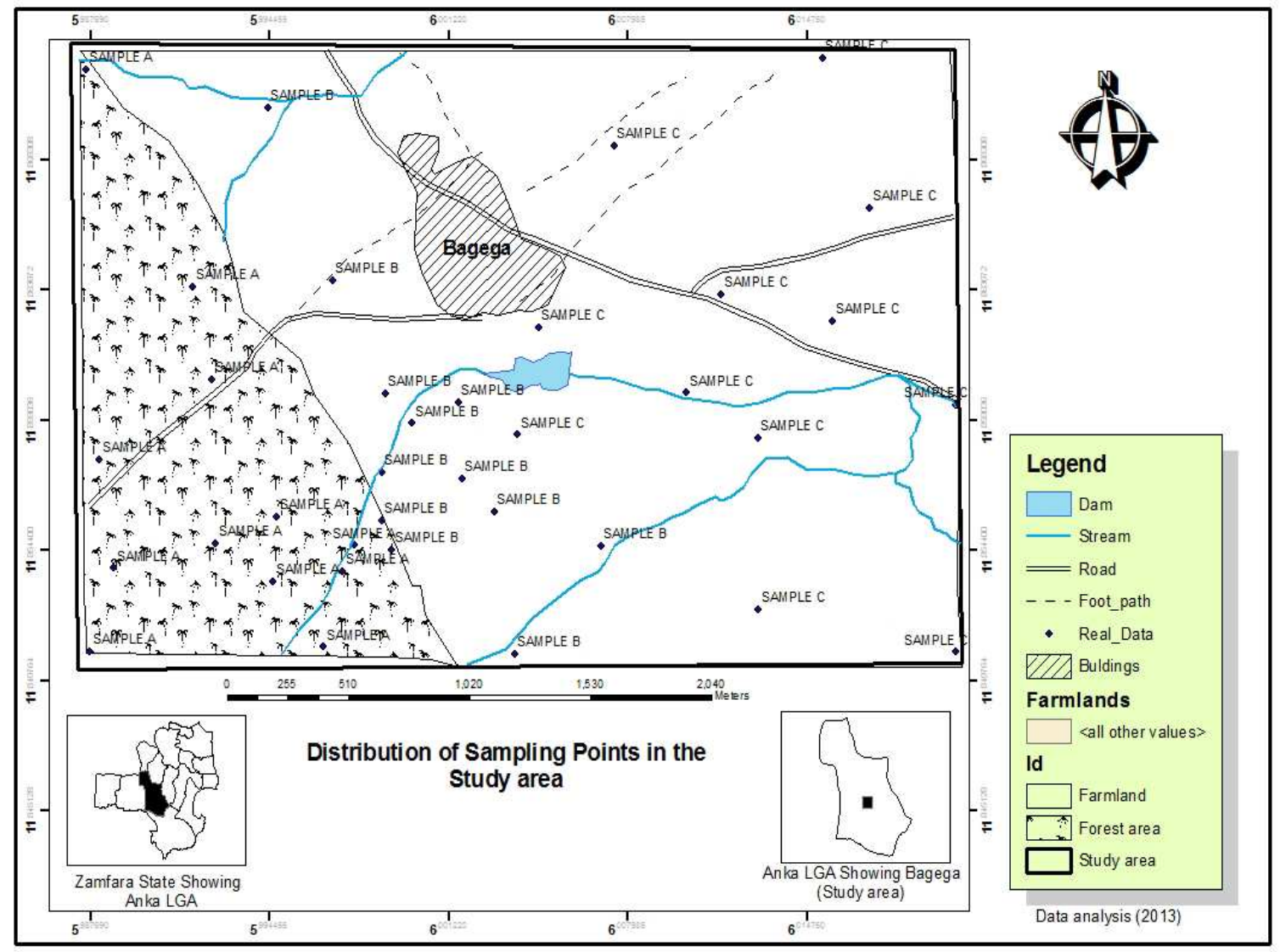

Figure 2: Sampling sites

\section{Mining Processing Area (MPA)}

This area is located few meters southwest of the Bagega settlement. This include the new mine site which was set up after the incidence of Bagega lead poisoning in May 2010. 
This area is thought to be polluted because of the mining activities (crushing, grinding, washing and drying) taking place in the area and also the discharge of the mine waste. Soil samples were collected from around the crushing, grinding, washing and dump sites.

\section{The Surrounding Farmlands (SF)}

These are areas that surround the mining processing environment, where rain fed farming is taking place. Most of these farmlands are situated on wind ward direction and where water current used to flow. Strong winds from the mining waste areas displace fine particles containing heavy metals and deposit these in adjacent farmlands. Also residual water current from the mining sites with possibly heavy metals in solution move into the surrounding farmlands. This area is expected to have heavy metals in the surface layer of the soils.

\section{The Residential Exterior (RE)}

The residential exterior is located east of Bagega settlement few kilometers away from the current mining processing area. The residential exterior selected might have been the abandoned and altered old mining processing unit which was under cultivation. This also form areas where Government changed/replaced the soils especially inside the village, because of the outbreak of Lead poisoning in 2011.

\section{Sampling Frame and Technique}

Three sets of samples were collected from the top (0$15 \mathrm{~cm}$ ) horizon, using stainless steel shovel. This is because the heavy metals pollution is expected to be mainly in the top soil profile.At the mining processing area, samples were collected using stratified random sampling techniques. This was done because the mining processing environment is expected to be the most polluted area. Thus, the contaminated soil of the mining environment was divided into four zones where samples were collected. The four zones includes crushing zone, grinding zone, washing/drying zone and dump waste zone. Three samples were collected each from the crushing, grinding, washing and dump sites making twelve (12) samples in the unit.

Several farmlands surrounding mining processing environment were observed receiving heavy metals through wind dust and water current. In order to get those farmlands under heavy metals, Stratified sampling was employed. Three farmlands were selected and four samples were collected in each farmland. The farmlands were selected based on the relative proximity to sources of industrial pollutants and the level of agricultural activity at the site.

The residential exterior is an area a few kilometers away from the current mining processing area. This is meant to be an area outside the sphere of influence of heavy metals from the current mining processing unit, but may have the influence of the old mining processing activity. However, the area has the same topography with the other two areas. Twelve samples were collected randomly in the area. However the area is very large, 3 to 5 samples were collected on a particular site and bulked (composite) before taking a sub sample for the farm.

\section{Soil analysis techniques}

The soil samples collected were air-dried at room temperature and lightly ground with agate mortar and pestle and pass through $2 \mathrm{~mm}$ sieve for analysis.

\section{(a) Digestion of soil samples for heavy metals}

Wet digestion method was used in which $10 \mathrm{~g}$ of airdried, ground and sieved sample was weighed into a clean $30 \mathrm{~cm}^{3}$ platinum crucibles, followed by the addition of the mixture of $\mathrm{HCL} / \mathrm{HNO}_{3}$. The soil mixture was then heated on a hot plate at a temperature between $80-90^{\circ} \mathrm{C}$. It was further heated at $100^{\circ} \mathrm{C}$, then the crucible with the content was allowed to cool and $10 \mathrm{~cm}$ of distilled water was added (Yusuf, 2010). This was filtered and used for the determination of the heavy metals $(\mathrm{Cu}, \mathrm{Fe}$ and $\mathrm{Zn}$ ). The digestion was done in triplicate and blank solution was also prepared and used for the background checks (Van Loon, 1980). The Atomic Absorption Spectrophotometer (AAS) (Alpha 4 Digital Model) equipped with a digital read out and a deuterium background correction system was used for the analysis. The concentration of the heavy metals in $(\mathrm{mg} / \mathrm{kg})$ were determined, these include Cadmium, Chromium, Zinc, Manganese, Iron, Copper, Lead and Nickel.

\section{(b) Determination of soil $\mathbf{p H}$}

To determine the $\mathrm{pH}$ value, $10 \mathrm{~g}$ of soil samples was weighed into a small beaker. Then $25 \mathrm{ml}$ of distilled water was added into the beaker and stirred for ten minutes. The content was then allowed to settled and then stirred for another ten minutes, while waiting for the second stirring the $\mathrm{pH}$ meter was calibrated using Buffer solution. The $\mathrm{pH}$ meter electrode was inserted into the soil sample and the value indicated on the meter was taken and rinse the electrode. The $\mathrm{pH}$ meter electrode was then inserted into the remaining samples and took the readings, this was continued to the last sample. The $\mathrm{pH}$ was determined because metal transport in soil is not only dependent on the physiochemical properties of the metals, but mostly on the physical and chemical properties of the soil like $\mathrm{pH}$ which determines the binding ability of soil. Thus, the amount of heavy metals in soils depends on the $\mathrm{pH}$ value (Dube, et al., 2000).

\section{Data Analysis}

The data were analysed in two phases, the first was the use of statistics while the second was the mapping. Descriptive statistics and were used to show and compare the concentration of the heavy metals among the three sites using graphs and tables in the Microsoft excel. While in the second phase was the use ofKrigging interpolation techniques (mapping) were used to show the spatial distribution of the heavy metals within the 3 study sites.Krigging is a group of statistical technique used to interpolate the value of a random field at an unobserved location from observation of its value at nearby locations (AhmedandJeb, 2014). This technique (krigging) aim at estimating the value of an unknown real valued function at a point, given the values of the function at some other points. 
The concentration levels were evaluated against the European Regulatory Standard. The European Regulatory Standard is quite accepted worldwide and has been used in most of the developing countries. Some other simple statistical techniques such as means, standard deviation and coefficient of variation were used.

\section{RESULTS AND DISCUSSION}

Concentration and Variation of $\mathrm{Cu}, \mathrm{Fe}, \mathrm{Zn}$ and pH in the study area

Recorded data from this study (Table 1) indicates that copper was detected in soil with an average concentration of $3.11 \mathrm{mg} / \mathrm{kg}, 2.04 \mathrm{mg} / \mathrm{kg}$ and $2.33 \mathrm{mg} / \mathrm{kg}$ for mining processing environment (MPA), surrounding farmlands and residential exterior (RE) respectively. The highest concentration was found at the mining processing environment, which is an indication that there is a release of Copper into the environment as a result of mining activities. This observation coincides with that of Brady (1984) that heavy metals particularly $\mathrm{Fe}, \mathrm{Cu}$ and $\mathrm{Zn}$ are normally present in large amount in the parent materials. Therefore mining of mineral deposits enhance the distribution of these metals. The lowest concentration of Copper was found at the surrounding farmlands (SF); therefore the area is not affected by both current and old mining activities in respect of Copper.The individual levels of heavy metals shows the highest Copper at the mining processing environment and the lowest levels was found at the surrounding farmlands. Copper (Cu) is an essential micronutrient in living organism with well define role in body metabolism, though at elevated concentration could tend to be toxic.

Table 1: The mean concentration of heavy metals and pH in the 3 sites understudy

\begin{tabular}{lcccc}
\hline Sites & $\mathrm{Cu}$ & $\mathrm{Fe}$ & $\mathrm{Zn}$ & $\mathrm{pH}$ \\
\hline Mining processing environment (MPE) & $\mathbf{3 . 1 1 1}$ & $\mathbf{1 2 . 9 9 3 8}$ & $\mathbf{5 . 0 9 7 1}$ & $\mathbf{5 . 8 2 5}$ \\
Standard deviation & 3.69 & 8.09 & 1.49 & 2.6 \\
Coefficient of variation (CV) & 1.19 & 0.62 & 0.29 & 0.45 \\
\hline Farmlands (SF) & $\mathbf{2 . 0 4 4}$ & $\mathbf{3 0 . 7 0 9 9}$ & $\mathbf{7 . 2 4 1 1}$ & $\mathbf{6 . 2 0 8}$ \\
Standard Deviation & 0.25 & 33.95 & 1.88 & 4.9 \\
Coefficient of variation (CV) & 0.122 & 1.11 & 0.26 & 0.79 \\
\hline Residential Exterior (RE) & $\mathbf{2 . 3 4}$ & $\mathbf{6 2 . 2 9}$ & $\mathbf{9 . 5 3}$ & $\mathbf{6 . 0 7}$ \\
Standard Deviation & 0.36 & 23.89 & 2.13 & 19.7 \\
Coefficient of variation (CV). & 0.15 & 0.38 & 0.22 & 3.25 \\
\hline
\end{tabular}

Source: Field work \& Lab Analysis(2013)

Copper is adsorbed to a greater extend by soils and soil constituents than most other heavy metals with the exception of lead (Ogabielaet al., 2010).

The result of the study revealed that the mean concentration for iron in the three areas was all found to be quite high. The mean concentration of iron in the soil of these sites were found to be $12.99 \mathrm{mg} / \mathrm{kg}$, $30.71 \mathrm{mg} / \mathrm{kg}$ and $62.29 \mathrm{mg} / \mathrm{kg}$ for mining processing environment, farmlands and residential exterior respectively (Table 1 and figure 2). The reason for the general high iron content in the area can be attributed to the fact that the metal constitutes high percentage of the total elements of the earth's crust (Mitchel, 1964). Moreover this could be as a result of climatic factors as observed by Aubert and Pinta (1977) that soils in the tropical climate zones (which Nigeria is among) are mostly ferralitic and has high iron content. The trend of Iron show less concentration in the mining processing area. The highest individual value was found at residential exterior and the lowest value was obtained at the mining processing environment.

The mean concentration value for Zinc is $5.09 \mathrm{mg} / \mathrm{kg}$, $7.24 \mathrm{mg} / \mathrm{kg}$ and $9.53 \mathrm{mg} / \mathrm{kg}$ for mining processing environment, farmlands and residential exterior respectively (Table 1 and figure 2). Zinc was found in abundance in the soil of the residential exterior, significantly higher than in the other 2 areas. This is not surprising because the area has been the old mining processing unit that exposed large quantities of metals due to weathering of parent rocks and the impacts of mining operations may persist long after operations have ceased.

The mean $\mathrm{pH}$ values of the farmlands and the residential exterior are 6.2 and 6.1 respectively (Table1 and Figure 3 ). The slightly acidic $\mathrm{pH}$ recorded for the farmlands and residential exterior is within the range of agricultural soil. From figure 2, the mining processing environment has the least $\mathrm{pH}$ value which is acidic. This implies that the area might induce more dissolution of heavy metals. In the farmlands and residential exterior slightly acidic soil $\mathrm{pH}$ value was observed. This variation in the value of the soil $\mathrm{pH}$ of the three areas could be attributed to the nature of the soils especially as it relate to their anthropogenic activities such as mining and farming.

Spatial distribution of Iron (Fe), Zinc (Zn) and Copper(Cu)

Iron and Zinc have similar spatial distribution in the studied areas; their distributions show the high accumulation in the Northeast, Centre and Southeast of the area with decreasing concentrations from the North East and South East to the West. Highest concentration of Iron (Figure 4) was found in the Residential Exterior, heavily concentrated and seems to be affecting the Surrounding Farmland to the west. The concentrations were found to be minimal in the mining processing environment. 
Bajopas Volume 9 Number 1 June, 2016

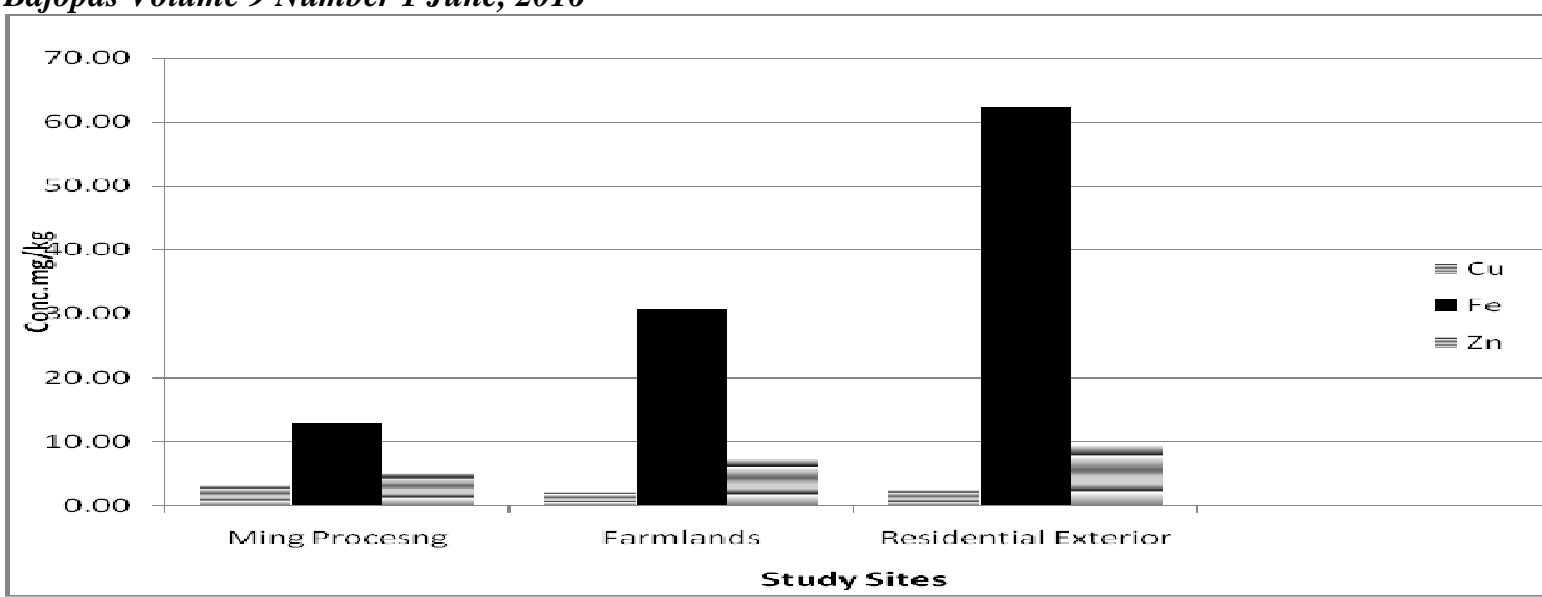

Figure 2: Mean concentration of $\mathrm{Cu}, \mathrm{Fe}$ and $\mathrm{Zn}(\mathrm{mg} / \mathrm{kg})$ among the 3 study sites

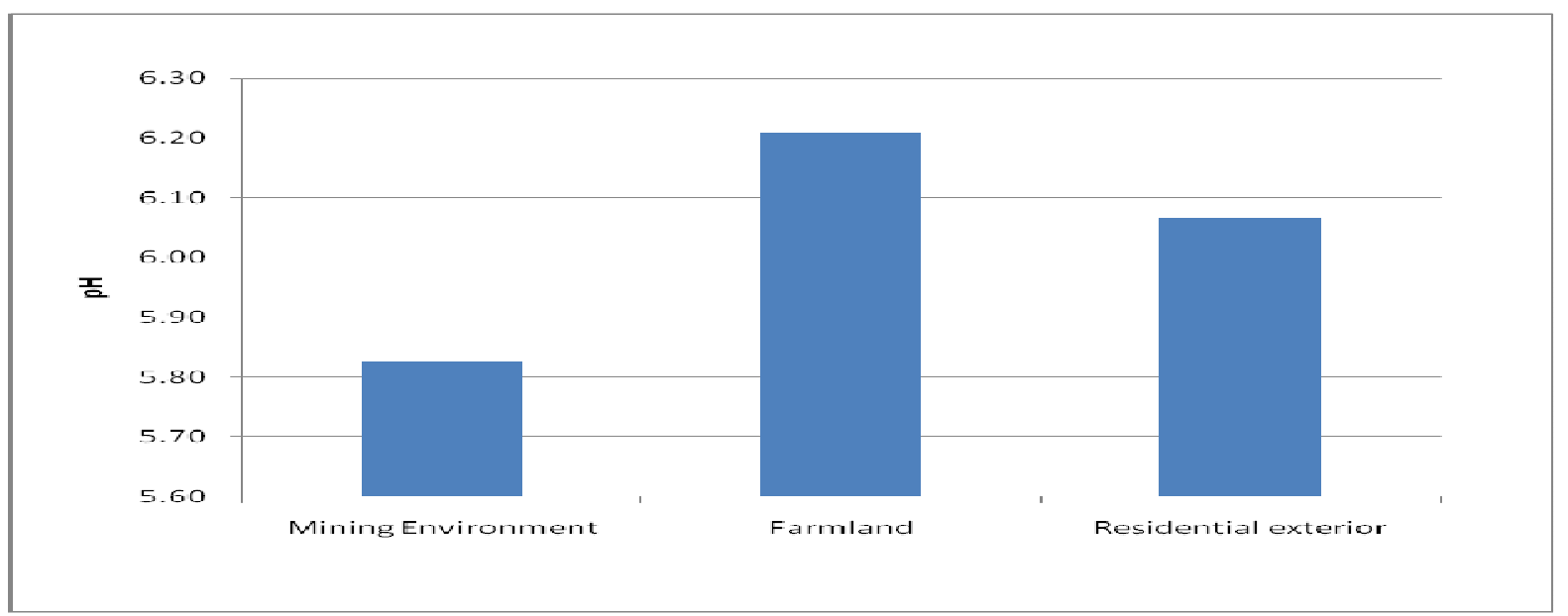

Figure 3: pH ratio of the three areas

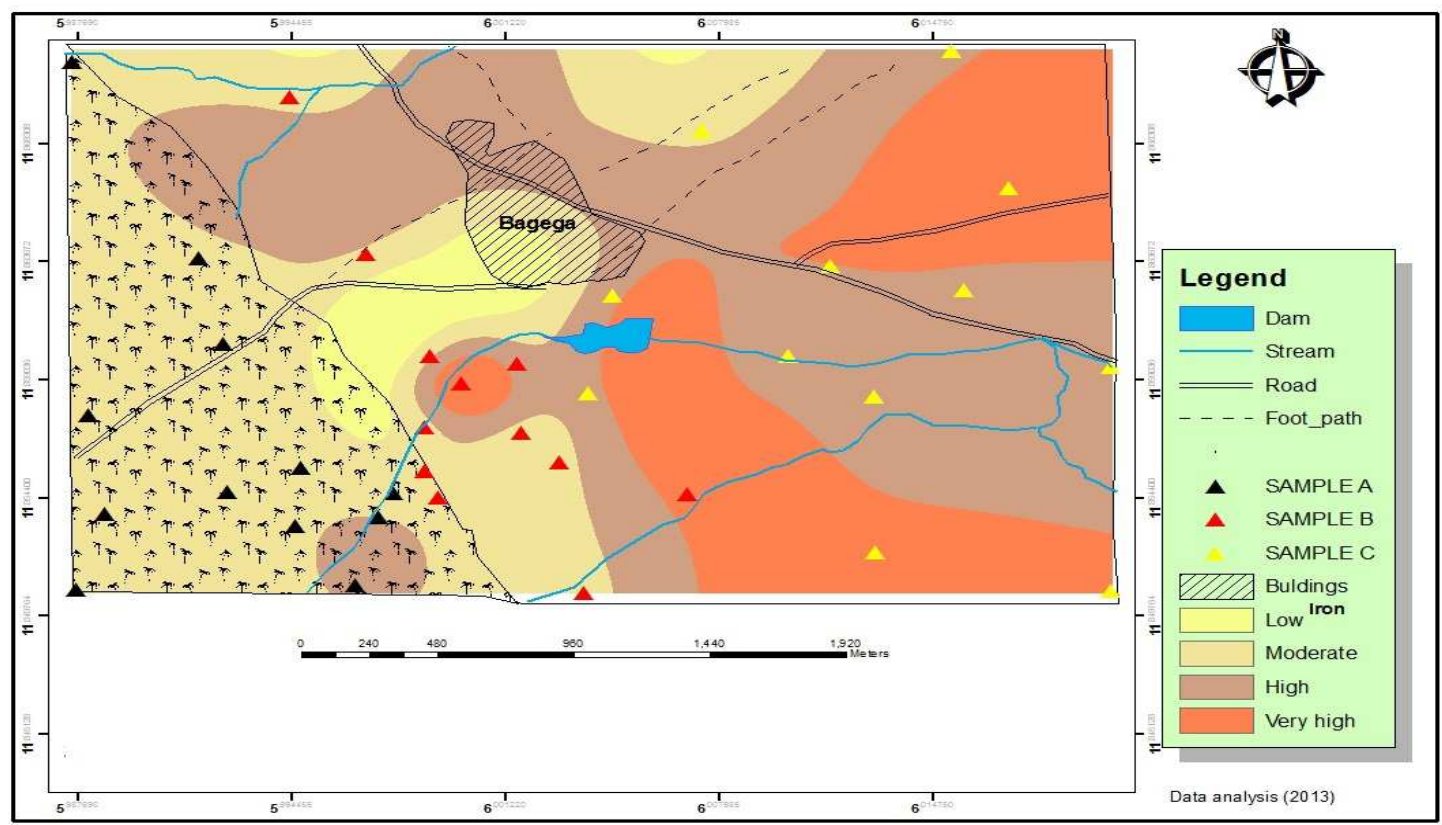

Figure 4: Spatial Distribution of Iron (Fe) in the Study area

The reason for the high Iron content in the residential exterior could be attributed to the fact that iron is among the group of metals that constitute over $99 \%$ of the total element content of the earth's crust. Moreover this could be as a result of the climatic factor as observed by Aubert and Pinta (1977) that 155 soils in the tropical climate zones are mostly ferralitic. The low level of iron in the mining processing environment is not surprising because as the time of this study, the area is the newly mapped out mining sites after the incidence of lead poisoning in Bagega 
Bajopas Volume 9 Number 1 June, 2016

Village. In spite of this, the area has low concentration of iron.

Highest concentration of Zinc was found in the residential exterior, followed by the surrounding farmlands. The least value was found at the mining processing environment. Mining waste usually introduced metallic Zinc into the soil (Figure 5). The distribution of Zinc in the residential exterior could be attributed to improper dumping of mine waste in the area. This might be responsible for high concentration of Zinc in the soil of the residential exterior because heavy metals once introduce to the soil may spread to the various components of the soils.
Low concentrations of copper were found in the MPA i.e. South West of the region (Figure 6), the concentration seems to be much more in a spot. Thus, it is probably not be distributed by rain or air. The high content of copper in the South West is mainly due to land use pattern (mining) in the region. Mining activities such as crushing, grinding, washing, and drying were the dominant activities in the Southwest region. It has been reported by Dara (1993) that a biodegradable waste introduced metallic copper into the soil. This may contribute to the high concentrations of copper in the soils of the South west.

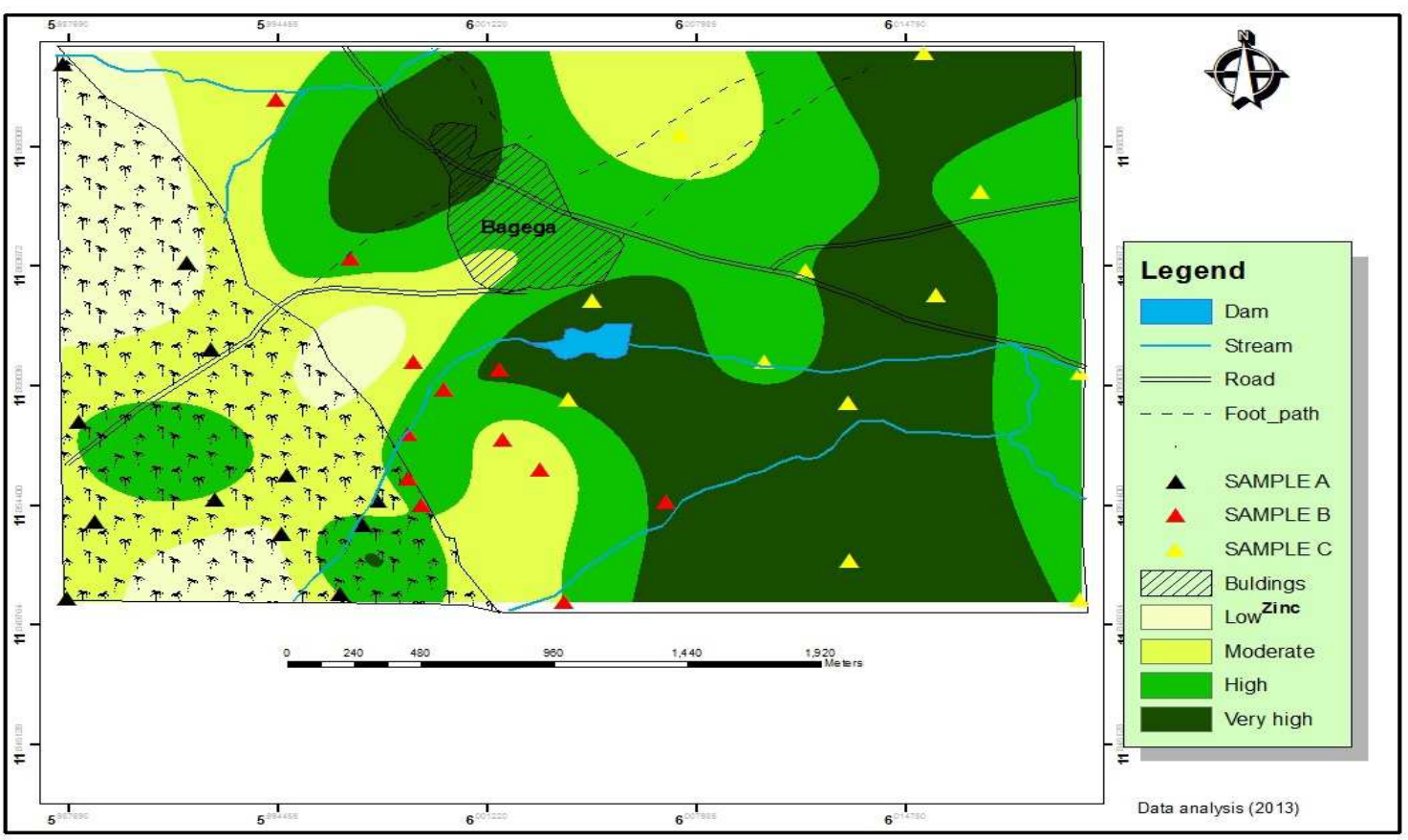

Figure 5: Spatial Distribution of Zinc (Zn) in the Study area

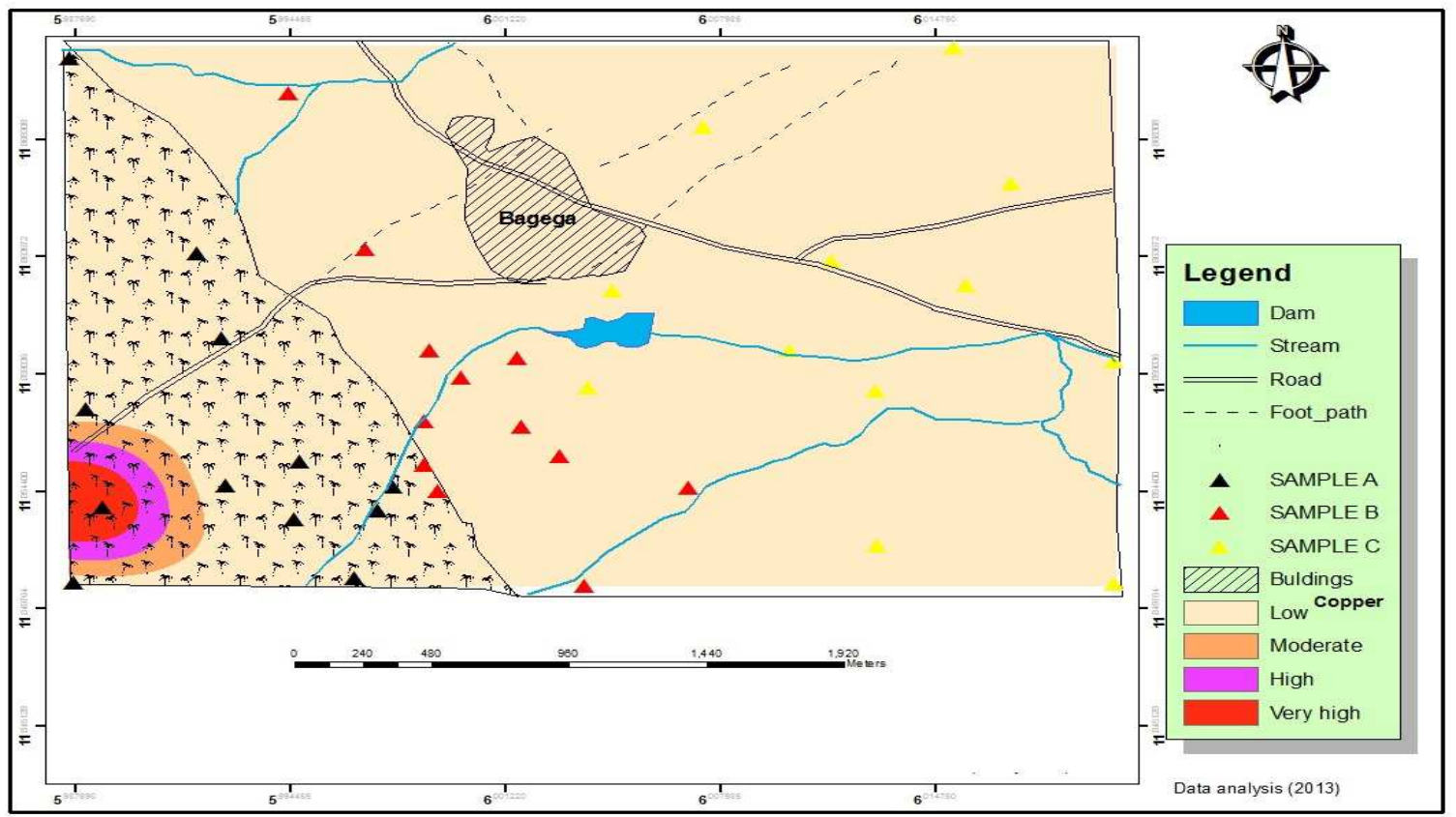

Figure 6: Spatial Distribution of Copper $(\mathrm{Cu})$ in the Study area 
Bajopas Volume 9 Number 1 June, 2016

The results of the heavy metal concentrations in the soils of the study area are therefore compared with European Standard (Hungarian) in view of such standards being absent in Nigerian standards.Comparing the mean values of heavy metals from the three sites against the European standard (Table 2), it could be observed that all the heavy metals within the three sites were far below the safe limits of Hungarian threshold standard. That is the concentrations are within the safe limits. Thus, none of the toxic metals recorded worrisome mean concentration. Despite the high value of $\mathrm{Fe}$ in the residential exterior $(62.29 \mathrm{mg} / \mathrm{kg})$ compared to farmland and mining processing environment, it is still at low level with reference to regulatory limits as shown in Table 2. Therefore the heavy metals show the least of these limits and as such have not surpassed the limits allowable in soil by regulatory agencies.

Table 2: The mean Concentration of Heavy Metals in the 3 sites against European Regulatory Standard

\begin{tabular}{|c|c|c|c|c|}
\hline \multicolumn{5}{|c|}{ Sites } \\
\hline METALS & $\begin{array}{l}\text { MINING-PROCESSING } \\
\text { ENVIRONMENT }(\mathrm{mg} / \mathrm{kg})\end{array}$ & $\begin{array}{l}\text { FARMLANDS } \\
(\mathrm{mg} / \mathrm{kg})\end{array}$ & $\begin{array}{l}\text { RESIDENTIAL } \\
\text { EXTERIOR } \\
(\mathrm{mg} / \mathrm{kg})\end{array}$ & $\begin{array}{l}\text { EURS(HUNGARIAN } \\
\text { THRESHOLD LIMIT) }\end{array}$ \\
\hline $\mathrm{Cu}$ & 3.11 & 2.04 & 2.34 & 30 \\
\hline $\mathrm{Fe}$ & 12.99 & 30.71 & 62.29 & NA \\
\hline $\mathrm{Zn}$ & 5.10 & 7.24 & 9.53 & 200 \\
\hline
\end{tabular}

Source: Data analysis (2011)

\section{DISCUSSION}

Soil is the major reservoir for contaminants and it has an ability to bind various chemicals. These chemicals can exist in various forms in the soil and different forces keep them bound to soil particles. Diverse amounts of heavy metals may be found everywhere in the soils (Dubeet al.,2000).Also, the level of mining activities in the new mining site could be continued, but the long term building up of these heavy metals over time is likely to damage the agricultural soils, particularly the soils of farmlands and residential exteriors. The study shows low limits of these heavy metalsespecially in the current mining processing environment was because the area is the newest mining environment that was established after the lead poisoning of Zamfara state that occurred in Bagega village in May, 2010. But this contradict the studies conducted by Adamuet al., 2011; Tsuwanget al., 2014; Yusuf et al., 2007, which show the soil to have high amount of heavy metals. Thus, it should be noted that regulatory data were not wholesomely available for all the metals for the different environment particularly soil, thereby making data comparison for safe limits a fairly difficult task (Ezejiforet al., 2012). Specifically, an important approach in this study was to compare the data obtained with the average concentration of these heavy metals in Nigerian soil (that is, baseline value for Nigerian soil) and this was not available. This indicates that there is a lack of regulatory standard or legal limits of heavy metals for soils in Nigeria.Therefore this further point out the dangers of having no clear Nigerian standards for heavy metals concentration limits in soils (Tudunwada, 2007).

Analysis of variance (ANOVA) was used to compare the levels of heavy metals in the three areas. Ranking of coefficient of variation (CV) of soil properties into different classes including least $(<15 \%)$, moderately $(15 \%-35 \%)$, and highly (>35) variable according to Wilding (1985). Therefore, the result (Table 2) shows that in the mining processing environment $\mathrm{Cu}, \mathrm{Fe}$ and $\mathrm{pH}$ are found to be highly variable in the area followed by $\mathrm{Zn}$ to be moderately variable. Fe and $\mathrm{pH}$ are highly variable. In general, $\mathrm{pH}$ shows to be highly variable in all the sampled areas followed by Fe.Variations in soil variables may be related to such factors as soil forming processes, sources of variables (geogenic and anthropogenic), geochemical characteristics of the soil as well as soil biology. High variability of soil attributes indicates multiple sources, heterogeneity in sources or geochemical process controlling the distribution of the variable (Kabata and Pendais, 2002). This result is in conformity with the findings of Adamuet al., (2011) which shows that Zn, $\mathrm{Fe}, \mathrm{Cu}$ to be highly variable in mining field and it also shows that $\mathrm{pH}$ having the least variable while is in contradiction with the result of our study area which indicated to be highly variable in all the sampled area.

\section{CONCLUSION}

The study had shown that the selected heavy metals $(\mathrm{Cu}, \mathrm{Fe}$ and $\mathrm{Zn})$ are found in low concentrations and are below acceptable limits. However, there are disparities in concentration of these heavy metals as regard to the different mining activities taking place. This distribution shows that there are more concentrations of Fe and $\mathrm{Zn}$ at the mining and Dam sites and a concentration of $\mathrm{Cu}$ at the farmland sites. There is also the probability that concentrations of the metals will increase after a long period of mining operations in the area since most of the metals investigated show higher values in the mining areas than the other areas.

Based on the findings of the study, this work recommends for;

i. That mining activities in the new mining site could be continued but with caution, because the long term building up of these heavy metals especially lead over time is likely to cause immediate and long term damage to the soil ecosystem. This calls for continual monitoring of heavy metals on concentration at the mining site.

ii. The local miners should also avoid conducting mining activities close to residential areas, farmlands and water bodies. Mining should be restricted to specified location with attendant facilities to improve the efficiency and economics of the operation. 
Bajopas Volume 9 Number 1 June, 2016

iii. Finally, further studies should go beyond soils to include water, plants and air. Once the concentration of the heavy metals has been identified, immediate action should be taken before it causes a serious effect.

\section{Authors' contributions}

This work was carried out in collaboration between all authors. Author SK performed the data source, analysis and interpreted the result and the first draft of the manuscript, YMA supervised the work. AM and MMU checked the analyses and the interpretation and

\section{REFERENCES}

Adamu C. I., Nganje T. N., Ukwang E.E., Ibe K. A. and Peter N. (2011) A Study of the Distribution pattern of Heavy metals in surface soils around ArufuPb-Zn mine, Northeastern Nigeria, Using Factor Analysis Research Journal of Chemical SciencesVol. 1 (2) Res. J. Chem. Sci.

Ahmed M. and D. N. Jeb (2014) Land Suitability for Sorghum Using Multicriteria Evaluation (MCE) and Analytical Hierarchy Process (AHP) in Bunkure Kano State, Nigeria. Journal of Agriculture and Veterinary Science (IOSRJAVS) e-ISSN: 2319-2380, p- ISSN: 2319-2372. Volume 7, Issue 9 Ver. IV PP 2537www.iosrjournals.orgwww.iosrjournals.org

Ahmed M, Jeb D. N, Usman A. K., Adamu G. K and Mohammed M. U. (2015) Spatial Distribution and Assessment of Selected Soil Physiochemical Parameters Using GIS Techniques in Bunkure Kano State, Nigeria International Journal of Plant \& Soil Science 5(3):143-154,IJPSS.2015.068 ISSN: 2320 7035 SCIENCEDOMAIN international www.sciencedomain.org

Aubert, H. and Pinta, M. (1977). Trace elements in soils. Development in Soil Science No. 7.pp 395Elsevier Scientific Publishing company, Amsterdam.

Boluda R., Andreu V., Pons V., Sánchez J., 1988.Contenido de metal espesados (Cd, Co, $\mathrm{Cr}, \mathrm{Ni}, \quad \mathrm{Pb}$ y $\mathrm{Zn}$ ) ensuelos de la comarca de La Plana de Requena-Utiel (Valencia).An Edafol Agrobiol 47, 1485-1502. [In Spanish].

Brady, N.C. (1984): The nature and Properties of soils. $9^{\text {th }}$ edition Macmillan, Inc New York.Centers for Disease Control and Prevention (CDCP) (2012) "Low Level Lead Exposure Harms Children: A Renewed Call for Primary Prevention" pdf. Retrieved 5 January 2012.

Dara, S.S., (1993): A text book of Environmental Chemistry and Pollution Control. S Chand and Company Ltd. Ram Nagar, New Delhi. 110055.

Dooyema, Carrie A., Neri, Antonio., Lo, Yi-Chun., Durant, James., Dargan, Paul I., Swarthout, Todd., Biya, Oladayo., Gidado, Saheed O., Haladu, Suleiman., Sani-Gwarzo, Nasir., Nguku, Patrick M., Akpan, Henry., Idris, draw the conclusion while UIA sourced the materials for the study area and other relevant literatures.

\section{Conflict of interest}

There is no conflict of interest between the Authors.

\section{Acknowledgment}

This is to acknowledge the contributions of Mallam Abubakar of the Soil and Water laboratory and Dr. M. M. Badamasi of the Department of Geography Bayero University Kano, for their assistance and guidance especially during data collection, analysis and presentation

Sa'ad., Bashir, Abdullahi M., and Brown, MaryJean. (2012) Outbreak of Fatal Childhood Lead Poisoning Related to Artisanal Gold Mining in Northwestern Nigeria, 2010. Environmental Health Perspectives. Vol. 120, No.4. pp. 601607.

Dowdy, R.H. and Volk, V.V. (1983): Movement of Heavy metals in Soil. In Chemical mobility and Reactivity in Soil Systems. D. W. Nelson (ed.) Soil Science Society of American Special Publ. Madison, WI, pp 220-240.

Dube et al., (2000): Adsorption and Migration of Heavy Metals is Soil. Polish Journal of Environmental Studies.Vol.10 No.1 pp1-10.

Ersoy A., Yunsel T.Y., Cetin M., 2004. Characterization of land contaminated by heavy metal mining using geostatistical methods. Arch Environ Con To 46, 162-175.

Ezejiofor, T.I.N.; Eke, N.V.; Okechukwu, R.I., Nwoguikpe, R.N.; Duru, C.M., 2011. Waste to wealth: Industrial raw materials potential of peels of Nigerian sweet orange (Citrus Sinensis). African Journal of Biotechnology Vol. 10(33), pp 6257-6264.

Ezigbor, V.O. (2011): Determination of the Trace metal Concentration in the soils of NNewi North Local Government area. Journal of Toxicology and Environmental Health Sciences.Vol 5 (1) pp. 1-11.

Federal Environmental Protection Agency (FEPA). (1995): Corporate Profile. Metro Prints LTD port Harcourt.

Galadima A (2012) Death toll from Zamfara state lead poisoning escalates as Nigerian Government remain sun perturbed. Sahara reporters, Available online at www.saharareporters.org (Accessed on September 2013)

Grabiel M.C., Williamson D.G., Brooks S.,Zhang H., Lindberg S., 2005. Spatial variability of $\mathrm{Hg}$ emissions from in a southeastern US urban environment.Environ Geol 48, 955964.

Hanesch M., Scholger R., Dekkers M.J., 2001. Theapplication of Fuzzy C-Means cluster analysis and non-linearmapping to a soil data set for detection of pollutedsites. PhysChem Earth Sci 26, 885-891. 
Bajopas Volume 9 Number 1 June, 2016

Imperato M. AdamoP., Naimo, D., ArienzoM., Stanzione D., and Violante P (2003) Spatial distribution of heavy metals in urban soils ofNaples city (Italy)Environmental Pollution 124; 247-256

Kabata P and Pendais $\mathrm{H}$. (2002), Trace elements in soil and plants Lewis, Beca Raton, USA, 365,5

Köppen, W., (1918) Classification of climates according to temperature, precipitation and seasonal cycle. Petermanns Geogr. Mitt., 64, 193203, 243-248.

Lar, U. A. (2013) Trace elements and health: An environmental risk inNigeriaEarth Science2(3): 66-

72(http://www.sciencepublishinggroup.com/j/ear th)doi: 10.11648/j.earth.20130203.11

Lar, U.A., Tsuwang, K. D. and Mangs, A. D. (2013) Lead and mercury contamination associated with artisanal gold mining in Anka, Zamfara State, north western Nigeria: a continuing story of the unabated Zamfara lead poisoning (unpublished M.Sc Thesis, University of Jos, Nigeria).

Leadership, (2012): Zamfara State Lead poisoning: a case still in Limbo. Posted with word press for Black Berry on February 13,2012.

Lickens, G.E. (2004): Effluent Monitoring. Journal For Shell Petroleum Development Company of Nigeria Ltd East.

Lij., W. Y., 1991. Historical changes of soil metal background values in select areas of China. Water Air Soil Poll57-58, 755-761. doi:10.1007/BF00282939.

Majiya M. H., Abdulmumin A. N., Sallau, M. S., Hussaini M. M. and Mohammed A. K. (2015)

Zamfara lead poisoning saga: Comparison of lead contamination level of water samples and lead poisoning in Bagega Artisanal gold mining district, Nigeria. Journal of Chemical and Pharmaceutical Research, 7(3):7-12

Mark O.A.O, Raymond L. N., Ugoeze U.E.and Adamu S. (2014) Heavy Metal Contaminations of Drinking Water Sources due to Illegal Gold Mining Activities in Zamfara State - Nigeria Journal of Chemistry and Biochemistry, Vol. 2, No. 1, pp. 31-44

McGrath, D. (1986): Heavy metals and the Environment, in Ghorbani et al (2002). Effects of Heavy metals on microbial populations and their activities, Faculty of Natural Resources, Karaj 31585, Iran. Symposium U- 54 no. 2234.

Mitchel, R.L. (1994): Chemistry of the soil $2^{\text {nd }}$ edition. John Willey and Sons, New York: USA: pp 268320.

National Population Commisson,(NPC) (2006): Estimated population of Zamfara State, Nigeria

Nigeria Ministry of Mines and Steel Development. (2010) Lead-Zinc: Exploration Opportunities in Nigeria.

Available: http://www.mmsd.gov.ng/downloads/Lead\%20Zi nc.pdf [accessed 22 August 2012].

Ogabiela et al., (2010): Determination of the levels of some elements in Edible oils sold in Zaria,
Northern Nigeria. Global Journals of Pure and Applied Sciences, vol.16 NO.3, 325-331.

Okonkwo, E.M and Eboatu, A.N.(1999): Environmental Pollution and Degradation. NoisExcell Publishing, Lagos 200pp.

Physical setting of Zamfara state, (2003): Retrieved from www.onlineniegria.com

Rodríguez M. J. A, Carbonell M. G, López A. Mand Grau C. J. M. (2009) Mercury content in topsoils, and geostatistical methods to identify anthropogenic input in the Ebro basin (Spain).Spanish Journal of AgriculturalResearch7(1), 107-118

Salomons, W. (1995): Environmental Impacts of Metals derived from mining activities: Process, Prediction,Prevention. Journal of Geochemical Exploration.52, pp2-23.

Tao S., 1995. Spatial structures of copper, lead, and $\mathrm{Hg}$ contentsin surface soil in the Shenzhen area. Water Air SoilPoll 82, 583-591. doi:10.1007/BF00479413.

Tsuwang, K.D., AjigoI.O. and Lar U.A. (2014) Assessment of Lead, Mercury and Arsenic in Soils ofAnka Area, North Western Nigeria. International Journal of Science, Environment ISSN 2278-3687 (O)and Technology, Vol. 3, No 1, 187 - 197

Tudunwada, I.Y. (2007); Determination of Heavy Metals in tannery sludge used for soil amendment in the portion of sorghum and millet crops around Kumbotso town. Unpublished Ph D. dissertation in the Department of Geography, Bayero University, Kano.

Van loon, C.V. (1980): Analytical Atomic Absortion Spectroscopy, Selected methods. Academic Press, Inc. New York, pp168-171.

Wilding, L. P. (1985) "Spatial Variability: Its Documentation, Accommodation, and Implication to Soil Surveys," In D. R. Nielsen and J. Bouma (eds). Soil spatial Variability. Purdon, The Netherlands, Wageningen, 1985, pp. 166-194.

Yi-Chun L.,Carrie A. D., Antonio N.,James D.Taran J.,Andrew M.,L.Douglas T.,Lora D., Raymond S. D.,Matthias Y. S.,Luka M. I.,Ossai O.,Nasir T. U.,Alhassan H. D. and Mary J. (2012) Childhood Lead Poisoning Associated with Gold Ore Processing: a Village-Level Investigation-Zamfara State, Nigeria, Environ Health Perspect 120:1450-1455

Yusuf, A.A., Abdu,N. and Tanimu, B. (2007): Assessment of Lead Contamination of Farmlands in Abare Village, Zamfara State. Proceedings of the $45^{\text {th }}$ Annual Conference of the Agricultural Society of Nigeria.Pp 487- 491.

Yusuf, M, A. (2010) Evaluation of Heavy metals in the soils of Urban and Peri-Urban irrigated Land in Kano, Northern Nigeria. Bajopa Volume 3, Number 2. Pp 46-51.

Zarcinas B.A., Pongsakul P., Mclaughlin M.J.,Cocens G., 2004. Heavy metal in soil and crops in southeast Asia. 2. Thailand. Environ GeochemHIth 26,359-371. doi:10.1007/s10653-005-4670-7. 